RESEARCH ARTICLE

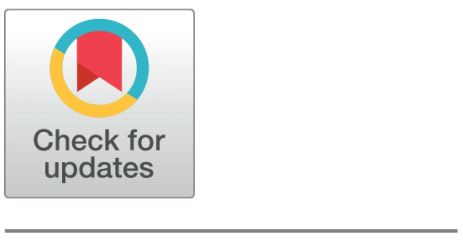

OPEN ACCESS

Received: 21-05-2020

Accepted: 30-05-2020

Published: 19-06-2020

Editor: Dr Natarajan Gajendran

Citation: Kumar S, Dhankhar R (2020) Assessment of change in soil properties before and after flooding due to the rainy season in Bhindawas wetland, Jhajjar, Haryana (India). Indian Journal of Science and Technology 13(20): 2057-2064. https://doi.org/ 10.17485/IJST/v13i20.689

Funding: None

Competing Interests: None

Copyright: (c) 2020 Kumar, Dhankhar. This is an open access article distributed under the terms of the Creative Commons Attribution License, which permits unrestricted use, distribution, and reproduction in any medium, provided the original author and source are credited.

Published By Indian Society for Education and Environment (iSee)

\section{Assessment of change in soil properties before and after flooding due to the rainy season in Bhindawas wetland, Jhajjar, Haryana (India)}

\author{
Sunil Kumar ${ }^{1}$, Rajesh Dhankhar ${ }^{2}$ \\ 1 Asst. Professor, Department of Environmental Science, Maharshi Dayanand University, \\ Rohtak, Haryana, India \\ 2 Department of Environmental Science, Maharshi Dayanand University, Rohtak, Haryana, \\ India
}

\section{Abstract}

Objectives: The purpose of the present study was to determine the changes in soil properties before and after flooding due to the rainy season in Bhindawas wetland. Method: A total of eighteen soil samples were collected from Bhindawas wetland, nine before and nine after flooding. Eighteen soil properties namely pH, electrical conductivity (EC), moisture content, exchangeable cations (sodium, potassium, calcium and magnesium), organic matter, total nitrogen, $\mathrm{C} / \mathrm{N}$ ratio, total phosphorus and heavy metals (iron, zinc, copper, lead, nickel, chromium and cadmium) were measured. Heavy metals were determined by using atomic absorption spectrophotometer (AAS). The principal component analysis (PCA) and hierarchical cluster analysis were performed on soil properties data. Findings: Student $t$-test for independent variables showed that statistically significant variation occurred before and after flooding in soil properties namely, $\mathrm{pH}$, moisture content, organic matter, total phosphorus, iron, zinc, lead and chromium. $85 \%$ variance in soil properties was shown by the first five PCs. The first PC explained the variation of $40.4 \%$, which related to $\mathrm{Zn}, \mathrm{Fe}, \mathrm{Mg}, \mathrm{Ni}$, $\mathrm{Cu}$ and $\mathrm{Pb}$ soil parameters. Dendrogram of hierarchical cluster analysis shows the two clusters with five sub-clusters. The findings of this study strongly suggested that degradation due to water logging in the non-submerged area during the rainy season change the soil properties in the wetland. Applications : Presently, Bhindawas wetland is severely affected by various environmental problems. Results of this study will prove useful in the development of an effective management plan for the Bhindawas wetland by various agencies.

Keywords: Soil properties; Bhindawas wetland; principal component analysis; hierarchical cluster analysis 


\section{Introduction}

According to Ministry of Environment and Forests (MoEF), India, the total area of wetland is estimated about 4.5 million hectares from which natural wetland occupied about 1.5 million hectares, man made wetlands are 2.6 million hectares (excluding paddy fields, rivers and streams), whereas 0.45 million hectares area occupied by mangroves ${ }^{(1)}$. Per unit wetland area losses in India create a greater impact as compared to other low populated countries with abundant wetlands, affecting the livelihood of rural Indian population, which depends on these natural resources ${ }^{(2)}$.

The health of the wetland ecosystem totally depends upon the soil quality. Physical, chemical and biological properties are the main indicators of soil quality ${ }^{(3)}$. Nutrients and water circulation by the soil decides the growth of vegetation, it also neutralized and reduced the bad effects of various pollutants ${ }^{(4)}$. Various factors like climate, topography, vegetation determines the soil composition and decides the capacity of the soil ${ }^{(5)}$. Release and retainment of nutrients in soil through time and space depend on overlying water quality conditions and other environmental conditions in the wetland soils ${ }^{(6)}$. The anthropogenic pollution sources, such as agricultural runoff, industrial wastewater and sewage have incremental effects on accumualtion of heavy metals in the soil. The high concentrations of heavy metals in soils generate the greatest threats to the wetlands biodiversity and food security ${ }^{(7)}$.

Soil column properties such as change in $\mathrm{pH}$ during the flooding, play significant role in diffusion flux of chemical species among the soil and overlying water. Water depth, duration of flooding and flooding frequencies are the other deciding conditions for changing soil quality dynamics ${ }^{(8)}$. The wetland structure and functions are significantly affected by changing soil quality. The quality of water, vegetation and animals in wetlands are significantly influenced by soil, because it acts as the most important biogeochemical regulator ${ }^{(9)}$. Recently, various researchers focussed their research on the influence of flooding and degradation on soil quality of the different ecosystems. Huang et al. ${ }^{(10)}$ demonstrated the effect of wetland degradation in the Yellow River Delta on soil properties. They find out that significant changes occurred in nitrate-nitrogen, ammonia-nitrogen, and $\mathrm{pH}$ after wetland degradation than before. Lewis et al. ${ }^{(11)}$ investigated variation in organic matter in Avicennia germinans mangrove forests and Juncus roemerianus salt marshes due to flooding and warming of soil. During experiments they found out that mineralizable carbon was greater at higher temperatures, but was lower with longer hydroperiods. Balasubramanian et al. ${ }^{(12)}$ studied the effects of floods on soil physico-chemical and biological properties in different land use systems present in and around the Burachapori wildlife sanctuary at North-East of India. Ren et al. ${ }^{(13)}$ investigated the wetland soil organic carbon concentration $(\mathrm{SOCc})$ at various sites and various depths by comparing four algorithms in Chinas Western Songnen Plain. However, few studies from India have been attempted to study the impact of the rainy season runoff on the various ecosystems soil properties. So far, soils of Bhindawas wetland have not been investigated in terms of change in properties due to rain flooding.

Bhindawas wetland was declared as a wildlife sanctuary in 1986 for the protection of biodiversity. But recently, this wetland degraded with time due to anthropogenic activities. The present study was an attempt to evaluate the change in soil properties after rain flooding because maximum degradation in wetland occurs during the rainy season. In the present time, Bhindawas wetland is severely affected by various environmental problems. The main pollution sources in this wetland includes, drain no8 as a point source, while agriculture runoff contribute the non-point pollution, the surrounding fields of farmers during the rainy season pumped excess water into the wetland. Aquatic invasive weed occupied about $70 \%$ waterlogged area of Bhindawas wetland. Main species are Eichhornia crassipes, Salvania molesta and Typha latifolia. Excessive phosphate and nitrogen nutrients level in water classified this wetland into the eutrophic lake ${ }^{(14)}$. The sediments deposition with the time reduces the depth, submerged area and water storage capacity of the wetland. The quality of water and the health of the wetlands ecosystem directly depend upon the quality of soil present in the wetlands. The present study was conducted with the aim to determine the soil quality before and after flooding by the rainy season. The Principal component analysis (PCA), student $t$-test and hierarchical cluster analysis were also performed on soil properties to determine the variation.

\section{Materials and Methods}

\subsection{Study area}

Bhindawas bird sanctuary is situated in district Jhajjar (Haryana). This wetland is $80 \mathrm{~km}$ away from the national capital Delhi in west direction and $15 \mathrm{~km}$ from district headquarter Jhajjar, located at $76^{\circ} 32^{\prime}$ East and $28^{\circ} 32^{\prime}$ West 1 ). Haryana Government in 1985 declared this wetland as a wildlife sanctuary for the purpose of protecting and developing wildlife, migratory birds are the main attraction of this wetland. About 250 migratory and native birds' species come to the wetland in the winter months. For this wetland, a total area of 1074 acres low-lying land of surrounding villages utilized by the government to store the escaped water of the Jawaharlal Nehru canal through an escape channel at the time of power failure of the canal system. Five villages viz. 

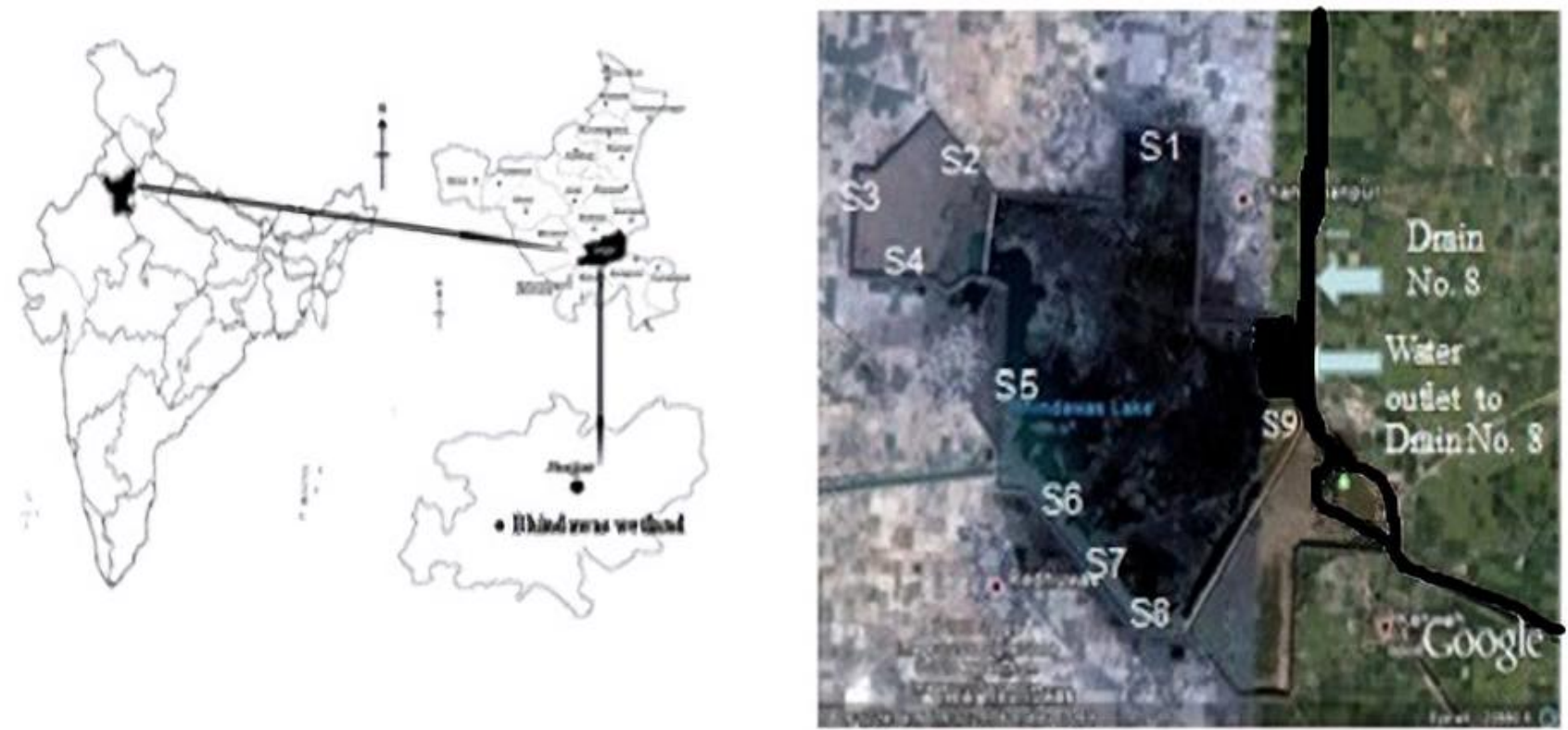

Fig 1. Study area with sampling locations

Kanwash, Nawada, Sajapur, Chadwana and Radhuwas are located near to this wetland. The water of wetland is used for domestic and agriculture purposes by villagers. Drain No.8 is the recipient of excess overflow water from the wetland, but during the rainy season due to a large volume of water in drain flow reversed, i.e. water entered from the drain into the wetland that is why this wetland is also used to protect drain and storage of rainwater during the rainy season.

\subsection{Soil sampling and analyses}

Figure 1 shows the soil sampling sites. A total of 18 soil samples were collected from Bhindawas wetland, nine samples collected before flooding in June month (2012), while nine samples collected after flooding in March month from the same locations. From each site composite soil samples were collected from the 10x10 meters plot area. At each location, the soil samples were collected from $0-10 \mathrm{~cm}$ depth below the surface, packed in polythene plastic bag and sealed. Initially in the laboratory, moisture content of soil samples was measured by the gravimetric method. Then, the field samples of soil were air dried on a tray. The dried samples were sieved over a $2 \mathrm{~mm}$ sieve and stored in airtight polythene begs. Sieved soil was used for the analysis of various soil properties viz., $\mathrm{pH}$, electrical conductivity (EC), organic carbon, phosphorous, nitrogen, $\mathrm{C} / \mathrm{N}$ ratio, exchangeable cations (potassium, magnesium, calcium and sodium) and total heavy metals (Fe, $\mathrm{Ni}, \mathrm{Cu}, \mathrm{Zn}, \mathrm{Cr}, \mathrm{Cd}$ and $\mathrm{Pb}$ ) accordance with Allen ${ }^{(15)}$. The $\mathrm{pH}$ of the soil samples was measured by $\mathrm{pH}$ meter in a 1:2 soil - water suspensions. The electrical conductivity (EC) of the soil samples was measured by Systonic soil and water testing kit based on the electrode method in a 1:2 soil - water suspensions. $1 \mathrm{~N}$ ammonium acetate extract was used to measure soil Exchangeable cations. Flame photometer model No. EP 902 was used to determine exchangeable $\mathrm{Na}$ and $\mathrm{K}$. While, EDTA titration method was used in the measurement of exchangeable Ca and Mg. Walkely and Black ${ }^{(16)}$ method was used to determine organic matter in soil. The total nitrogen of soil samples was estimated by the Kjeldhal method. Colorimetric method by using stannous chloride was used to analyze total phosphorus in soil samples. For the release of mineral elements from soil wet oxidation of samples was carried out using acids. $\mathrm{Fe}, \mathrm{Cu}, \mathrm{Zn}, \mathrm{Cd}, \mathrm{Ni}, \mathrm{Pb}, \mathrm{Cr}$ were determined by Polarized Zeeman Hitachi Atomic Absorption Spectrophotometer (AAS) model No. Z 8200. All samples were analyzed in triplicate. Analytical grade (AR) chemicals were used throughout the study. Certified stock solutions (Merck) of $1000 \mathrm{mg} / \mathrm{l}$ were used for preparation of heavy metals working standards.

\subsection{Statistical analyses}

Mean and standard deviation values of soil parameters, before and after flooding was determined by Microsoft excel 2007. Student's $t$-test between before and after flooding soil data at 5\% significant level was used to determine differences among wetland soil quality. Student's $t$-test, principal component analysis (PCA) and hierarchical cluster analysis of 18 soil samples 
were performed with the help of SPSS 14.0. Eigenvalues greater than 1.0 were taken in determining principal components (PCs). The Principal component analysis (PCA) are mainly used for the reduction of parameters to meaningful dimensionless variables in the form minimum data set (MDS) ${ }^{(17)}$

\section{Results and Discussion}

\subsection{Soil properties before and after flooding}

To examine the existing and temporal variation in soil quality of the area, a total of 18 soil samples were collected from Bhindawas wetland, nine samples collected before flooding in June month, while nine samples collected after flooding in March month from the same locations. Table 1 represents before and after flooding - the physical and chemical properties of Bhindawas wetland. Before flooding soil properties varied as $\mathrm{pH}$ (7.58-8.82), EC (365-1240 $\mu \mathrm{mho} / \mathrm{cm})$, Moisture content (9.5-15.1\%), \% Organic Carbon (0.94-1.34), \% T. Nitrogen (0.09-0.16), C/N ratio (8-11.6), Ex. Na (170-380 mg/kg), Ex. K (138-280 mg/kg), Ex. Ca (920-1320 mg/kg), Ex. Mg (203-342 mg/kg), T. Phosphorus (302-415 mg/kg), Fe (425-788 mg/kg), Zn (15-42 mg/kg), $\mathrm{Cu}(6.8-18 \mathrm{mg} / \mathrm{kg}), \mathrm{Ni}(7.8-21 \mathrm{mg} / \mathrm{kg}), \mathrm{Pb}(4.9-13 \mathrm{mg} / \mathrm{kg}), \mathrm{Cr}(5.9-20 \mathrm{mg} / \mathrm{kg})$ and Cd (0.24-0.86 mg/kg).

While, soil properties after flooding varied as $\mathrm{pH}(6.75-7.97)$, EC (420-1941 $\mu \mathrm{mho} / \mathrm{cm})$, Moisture content (17.2-30.2\%), \% Organic Carbon (1.2-1.7), \% T. Nitrogen (0.12-0.23), C/N ratio (6.9-11), Ex. Na (210-515 mg/kg), Ex. K (256-466 mg/kg), Ex. $\mathrm{Ca}$ (1060-1420 mg/kg), Ex. Mg (232-396 mg/kg), T. Phosphorus (350-1016 mg/kg), Fe (900-2105 mg/kg), Zn (33-123 mg/kg), $\mathrm{Cu}(8.2-36 \mathrm{mg} / \mathrm{kg}), \mathrm{Ni}(12-31 \mathrm{mg} / \mathrm{kg}), \mathrm{Pb}(10-19 \mathrm{mg} / \mathrm{kg}) \mathrm{Cr}(12-32 \mathrm{mg} / \mathrm{kg})$ and Cd (0.18-0.64 mg/kg).

\subsection{Comparison between before and after flooding soil properties}

Soil properties before and after flooding due to rainy season were recorded for wetland soil sites from S1 to S9. The mean values of different parameters have been given in Table 1. The mean value of $\mathrm{pH}$ at different sites was declined after flooding. EC was inclined by $25 \%$, the mean values of EC increased from 762 to $955 \mu \mathrm{mho} / \mathrm{cm}$ after flooding. While moisture content was remarkably increased by $96 \%$, the mean values of moisture content increased from 11.7 to $22.9 \%$ after flooding. The present study, revealed that soil $\mathrm{pH}$ in the wetland was decreased after flooding, which could be linked to an increased rate of decomposition in organic matter and subsequent conversion of released $\mathrm{CO}_{2}$ into carbonic acid. The results of $\mathrm{pH}$ were associated with Edicha et al. ${ }^{(18)}$ finding in which, it was observed that the soil $\mathrm{pH}$ had inverse relationships with soil organic matter. The increased level of moisture after flooding, soils were leading to rapid decomposition of peat, and resulted in increased acidity and the fertility of the soils ${ }^{(19)}$. In the present study mean values of $\mathrm{pH}$ were 8.02 before and 7.54 after flooding, which indicated the slightly alkaline nature of the soil. The activity of soil beneficial microorganisms are influenced by soil $\mathrm{pH}$, which ultimately made impact on plant growth. Strongly acidic soils reduce the growth of most nitrogen-fixing legume bacteria. Bacteria that decompose soil organic matter leads to release of nitrogen and other nutrients for plants use, hindered by strong acidity. Value of $\mathrm{pH}$ in the study area was good for decomposition and plant growth. Edicha et al. ${ }^{(18)}$ demonstrated that soil moisture content had positive correlations with soil organic matter in both wet and dry seasons. The texture and compactness of soil determined by the presence of moisture content, which ultimately decide its suitability to support life. The infiltration of water is the main source of moisture in the soil. However, the availability of moisture in soil depends on several factors such as water holding capacity, evaporation and plant uptake.

The organic carbon and total nitrogen average values were 1.09 and $0.12 \%$ before flooding, which increased gradually to 1.36 and $0.14 \%$ after flooding. Organic carbon, nitrogen and $\mathrm{CN}$ ratio showed the increasing trend by 25,17 and $2.2 \%$, respectively. The decomposition rate depends upon the available organic matter in soil and moisture content. Organic carbon is an index of soil productivity and amount of carbon broken down from plants and animals that stored in the soil. The present study, revealed that organic carbon and moisture content increased after flooding. A similar study on wetland soil has been conducted by Deka et al. ${ }^{(20)}$ at Kapla Beel, a wetland in Barpeta district. Another study conducted by Singh et al. ${ }^{(21)}$ in montane habitats at Nanda Devi Biosphere Reserve (NDBR), India during wet and dry seasons, which indicated that in dry season carbon cycle processes and nitrogen cycle processes were low as compared to wet season. Their finding also suggested that dehydrogenase activity of soil microorganisms increased with increasing organic carbon. Further, water holding capacity of the soil improved with increasing organic matter and thereby promoting better growth of microorganisms that are responsible for nitrification. In the present study wet condition was available after flooding, because of more moisture content present in the soil of wetland. This might increase in the rate of decomposition of organic matter.

Exchangeable sodium, potassium, calcium and magnesium increasedby 15, 56, 10 and 17\%, respectively. The concentrations of exchangeable cations were higher after flooding, it could be due to the adsorption of cations by the soil from overlying water and degradation of vegetation during flooding season. The results of exchangeable cations are coinciding with data that have 
been reported from several forested wetlands ${ }^{(22)}$ and agricultural areas ${ }^{(23)}$. An average value of total phosphorus was $332 \mathrm{mg} / \mathrm{kg}$ before flooding, which increased gradually to $540 \mathrm{mg} / \mathrm{kg}$ after flooding. Total phosphorous was remarkably increased by $63 \%$.

Table 1. Bhindawas wetland soil properties before and after flooding $(\mathrm{n}=18)$

\begin{tabular}{|c|c|c|c|c|c|c|c|}
\hline \multirow{2}{*}{ Soil Properties } & \multicolumn{3}{|c|}{ Before flooding $(n=9)$} & \multicolumn{3}{|c|}{ After flooding $(n=9)$} & \multirow{2}{*}{$\begin{array}{l}\text { \%age difference in } \\
\text { mean values }\end{array}$} \\
\hline & Range & Mean & Standard Deviation & Range & Mean & Standard Deviation & \\
\hline $\mathrm{pH}(1: 2)$ & $7.58-8.82$ & 8.02 & 0.36 & $6.75-7.97$ & $7.54^{\star}$ & 0.42 & -6.0 \\
\hline $\mathrm{EC}(1: 2)(\mu \mathrm{mho} / \mathrm{cm})$ & $365-1240$ & 762 & 277 & $420-1941$ & 955 & 534 & 25 \\
\hline Moisture content (\%) & $9.5-15.1$ & 11.7 & 2.10 & $17.2-30.2$ & $22.9^{\star}$ & 4.88 & 96 \\
\hline$\%$ Organic Carbon & $0.94-1.34$ & 1.09 & 0.14 & $1.2-1.7$ & $1.36^{*}$ & 0.16 & 25 \\
\hline$\%$ T. Nitrogen & $0.09-0.16$ & 0.12 & 0.03 & $0.12-0.23$ & 0.14 & 0.04 & 17 \\
\hline $\mathrm{C} / \mathrm{N}$ & $8-11.6$ & 9.48 & 1.06 & $6.9-11$ & 9.69 & 1.42 & 2.2 \\
\hline Exchangeable $\mathrm{Na}(\mathrm{mg} / \mathrm{kg})$ & $170-380$ & 281 & 67 & $210-515$ & $324^{*}$ & 87 & 15 \\
\hline Exchangeable K (mg/kg) & $138-280$ & 213 & 51 & $256-466$ & 333 & 79 & 56 \\
\hline Exchangeable Ca (mg/kg) & $920-1320$ & 1131 & 133 & $1060-1420$ & 1250 & 140 & 10 \\
\hline Exchangeable Mg (mg/kg) & $203-342$ & 272 & 45 & $232-396$ & 319 & 62 & 17 \\
\hline T. Phosphorus (mg/kg) & $302-415$ & 332 & 34 & $350-1016$ & $540^{*}$ & 239 & 63 \\
\hline T. Iron (mg/kg) & $425-788$ & 597 & 106 & $900-2105$ & $1518^{*}$ & 479 & 154 \\
\hline T. Zinc (mg/kg) & $15-42$ & 28 & 8.1 & $33-123$ & $55^{\star}$ & 26 & 96 \\
\hline T. Copper (mg/kg) & $6.8-18$ & 12.5 & 3.7 & $8.2-36$ & 18.5 & 8 & 48 \\
\hline T. Nickel (mg/kg) & $7.8-21$ & 13.9 & 4.6 & $12-31$ & 18.7 & 6.2 & 34 \\
\hline T. Lead (mg/kg) & $4.9-13$ & 8.7 & 2.5 & $10-19$ & $15.1^{\star}$ & 2.7 & 73 \\
\hline T. Chromium (mg/kg ) & $5.9-20$ & 12.6 & 4.8 & $12-32$ & $21.5^{\star}$ & 7.1 & 70 \\
\hline T. Cadmium (mg/kg) & $0.24-0.86$ & 0.5 & 0.2 & $0.18-0.64$ & 0.4 & 0.15 & -20 \\
\hline
\end{tabular}

${ }^{\star} \mathrm{P}<0.05$ ( $\mathrm{t}$ test independent variables)

Most heavy metals also showed an increased amount. Iron increased by $154 \%$, zinc $96 \%$, copper $48 \%$, nickel $34 \%$, lead $73 \%$, total chromium $70 \%$, respectively. Whereas the chromium showed the decline trend by $20 \%$ ( Table 1 ). The main reasons for increasing heavy metals concentration in the wetlands are agriculture runoff, domestic, municipal, and agricultural wastes, which include residues of heavy metal-containing pesticides ${ }^{(24)}$. When we compare our results of heavy metals with soil quality guidelines given by Indian Standard ${ }^{(25)}$ and European Union ${ }^{(26)}$ standards for soil, it was found that all the heavy metals were below the prescribed limit ( Table 2 ). The heavy metals were present in following sequence $\mathrm{Fe}>\mathrm{Zn}>\mathrm{Cr}>\mathrm{Ni}>\mathrm{Cu}>\mathrm{Pb}>\mathrm{Cd}$.

The results highlighted that the significant $(t$-test, $\mathrm{P}<0.05)$ variation found among the mean values of $\mathrm{pH}$, moisture content, organic carbon, total phosphorus, iron, zinc, lead and chromium before and after flooding. It could be due the after effect of floodwater, soil encountered with water logging problem in the non-submerged area for many months. This led to death and destruction of the small vegetation. The phosphorus and organic carbon absorbed by plants were returned back to the soil after flood degradation. However, nitrogen content inclined after flooding, but not significantly ( $\mathrm{P}>0.05)$, it could be due to the lower uptake of nitrogen by smaller plants, denitrification activity due to higher moisture content and leaching of nitrate in water-saturated soil. Moreover, pollutants and nutrients rich water retained from drain 8 and agriculture runoff also altered the soil properties. The outcome of the study also suggests that increment in exchangeable cations (sodium, potassium, calcium and magnesium) and heavy metals (Fe, $\mathrm{Cu}, \mathrm{Zn}, \mathrm{Cd}, \mathrm{Ni}, \mathrm{Pb}$ and $\mathrm{Cr}$ ) would be a cause of concern in the future. Drain $\mathrm{No} 8 \mathrm{was}$ protected by Bhindawas wetland because it stored excess volume of floodwater during the rainy season from the drain. But, this practice deteriorates the wetland heath by the addition of pollutants and nutrients, which changed the quality of soil as well as water. This wetland required immediate attention for controlling the intrusion of drain water during the rainy season.

Table 2. Reference values of various heavy metals in soil (mg/Kg)

\begin{tabular}{llllllll}
\hline Agencies & $\mathbf{C d}$ & $\mathbf{C u}$ & $\mathbf{P b}$ & $\mathbf{Z n}$ & $\mathbf{N i}$ & $\mathbf{C r}$ & $\mathbf{F e}$ \\
\hline Indian Standard (Awashthi, 2000) & $3-$ & $135-270$ & $250-500$ & $300-600$ & $75-150$ & - & - \\
& 6 & & & & & & \\
European Union Standards (EU, 2000) & 3.0 & 150 & 300 & 300 & 75 & 150 & - \\
\hline
\end{tabular}




\subsection{Principal Component Analysis (PCA of soil properties}

A mathematical procedure named PCA was used to determine a small number of uncorrelated variables called principal components (PCs) from the soil correlated variables. Maximum variability of soil parameters was presented by these PCs in the form of a minimum data set (MDS) ${ }^{(27)}$. In this study, PCA was used to reduce the dimensionality of the variables or attributes to new meaningful variables. Various attributes of PCA like PCs, eigenvalue, \%variance, cumulative \% and communalities were listed in Table 3. 85\% variance in soil properties was shown by the first five PCs. The first PC explained the variation of $40.4 \%$, which related to $\mathrm{Zn}, \mathrm{Fe}, \mathrm{Mg}, \mathrm{Ni}, \mathrm{Cu}$ and $\mathrm{Pb}$ soil parameters. The second $\mathrm{PC}$ explained $16.8 \%$ variation of soil properties, which was related to $\mathrm{K}, \mathrm{Na}, \mathrm{Ca}$ and moisture content. The third $\mathrm{PC}$ showed a variation of $11.3 \%$, which was related to nitrogen, organic carbon and Cr. The fourth and fifth PCs showed a variation of 10.3 and 6.4\%, related to phosphorus, $\mathrm{pH}, \mathrm{Cd}$ and EC. The highest variability has been shown by $1^{\text {st }} \mathrm{PC}$ in the given soil data, subsequently, variability reduction at each successive PCs levels. First, five principal components (PCs) have eigenvalues $>1$ and that each PC can explain at least $5 \%$ of data variation. Higher eigenvalues and variables with a high factor loading of PCs in the present study, indicated that the variables are best to represent the system attributes in PCA analysis. The highest communalities were showed by organic carbon, total nitrogen, $\mathrm{C} / \mathrm{N}$ ratio and zinc $(0.92,0.96,0.92$ and 0.91$)$, which were nearer to 1 and other soil properties had intermediate communality values indicating that soil properties data best fitted to PCA analysis.

Table 3. PCA results of 18 soil properties

\begin{tabular}{lllllll}
\hline Soil Properties & PC1 & PC2 & PC3 & PC4 & PC5 & Communalities \\
\hline pH & 0.075 & 0.085 & -0.078 & -0.315 & 0.094 & 0.802 \\
EC & -0.085 & 0.220 & -0.071 & 0.129 & 0.377 & 0.875 \\
Moisture content & -0.022 & 0.168 & -0.072 & 0.104 & -0.181 & 0.834 \\
\%age O. Carbon & -0.049 & 0.083 & 0.196 & 0.112 & 0.036 & 0.925 \\
\%age T. Nitrogen & -0.088 & 0.004 & 0.351 & 0.061 & 0.083 & 0.969 \\
C/N & 0.105 & 0.110 & -0.427 & 0.008 & -0.134 & 0.927 \\
Ex. Na & -0.133 & 0.295 & 0.072 & -0.149 & -0.149 & 0.838 \\
Ex. K & -0.053 & 0.310 & -0.116 & -0.009 & -0.083 & 0.839 \\
Ex. Ca & 0.048 & 0.227 & -0.042 & -0.068 & 0.152 & 0.830 \\
Ex. Mg & 0.084 & 0.172 & 0.005 & -0.187 & -0.029 & 0.880 \\
T. Phosphorus & -0.019 & -0.067 & 0.011 & 0.374 & 0.218 & 0.852 \\
T. Iron & 0.116 & -0.100 & 0.078 & 0.188 & -0.022 & 0.821 \\
T. Zinc & 0.237 & -0.100 & 0.017 & -0.005 & -0.046 & 0.915 \\
T. Copper & 0.291 & -0.003 & -0.156 & -0.097 & -0.016 & 0.863 \\
T. Nickel & 0.318 & -0.095 & -0.096 & -0.064 & 0.070 & 0.893 \\
T. Lead & 0.179 & -0.032 & -0.063 & 0.140 & 0.076 & 0.738 \\
T. Chromium & 0.061 & -0.099 & 0.195 & 0.084 & -0.050 & 0.712 \\
T. Cadmium & 0.036 & -0.096 & 0.122 & 0.062 & 0.590 & 0.882 \\
Eigenvalue & 7.287 & 3.032 & 2.048 & 1.865 & 1.162 & \\
\% of variance & 40.4 & 16.8 & 11.3 & 10.3 & 6.4 & \\
Cumulative \% & 40.5 & 57.3 & 68.7 & 79.1 & 85.5 & \\
\hline
\end{tabular}

\subsection{The hierarchical cluster analysis of data}

The hierarchical cluster analysis was performed using Ward's method to create groups among the soil samples, based on similar and dissimilarity in physical and chemical soil properties. A total of eighteen soil samples were taken, nine before and nine after flooding in the wetland. Figure 2 shows the dendrogram of eighteen samples. The dendrogram shows the two clusters with five sub-clusters. The first cluster consists of those samples $(18,16,14,12,17$ and 18) collected after flooding from the wetland. These sampling sites were exposed to overlying water for long time duration by the floodwater and adversely affected by the impact of flooding, which significantly changes the soil properties. The first sub-group in the second cluster shows the mixed samples of before and after flooding with similar soil characters. The soil samples $(15,11$ and 10$)$ were collected after flooding, having short duration of exposure to the floodwater with lower soil properties, while soil samples $(9,7$ and 5$)$ were those samples, which were 
collected before flooding from the area having abundant vegetation with higher soil character as compared to samples collected in the same duration. The second sub-group shows those soil samples $(1,4,6,2,3$ and 8$)$, which were collected before the flood and having intermediate vegetation on sites. The hierarchical cluster analysis highlighted that significant change occurred due to the floodwater and richness of vegetation. Dai et al. ${ }^{(28)}$ performed the hierarchical cluster analysis to categorize the various soils amendment with biochar. They demonstrated that all the treatments could be separated into four distinct groups. Similarly, Zolfaghari et al. ${ }^{(29)}$ used the hierarchical cluster analysis to identify the homogeneous desertification management units.

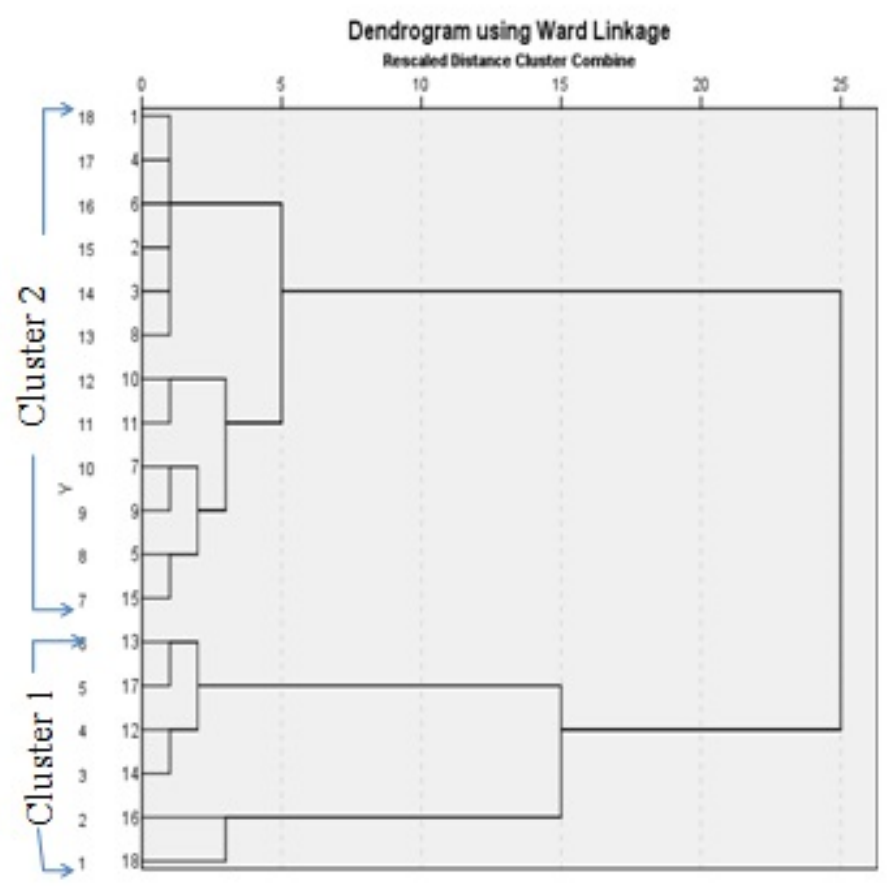

Fig 2. Hierarchical cluster analysis of 18 soil samples

\section{Conclusion}

It is concluded that significant change in soil properties namely, $\mathrm{pH}$, moisture content, organic matter, total phosphorus, iron, zinc, lead and chromium occurred after flooding due to the rainy season. These changes could be due to the pollutants received from point (drain No.8) and non-point source (agriculture runoff). In addition, water lying on the non-submerged area of the wetland during the rainy season and winter season degraded the vegetation. The $\mathrm{pH}$ value was decreased after flooding. Moisture content was increased by $96 \%$, which play the significant role in the decomposition of organic matter that leads to increase in organic and phosphorus in wetland soil. All the heavy metals were within the prescribed limit, but an increment has been observed after flooding, it could be due to the water received from the point and non-point sources of pollution during the rainy season. The five PCs explained the variation of 40.4, 16.8, 11.3, 10.3 and $6.4 \%$. Higher Communalities value in PCA indicated the good variability among soil properties. The soil properties' values are useful for the development of an effective management plan for Bhidawas wetland, which is presently facing several environmental problems. However, this study only focused on the impact of flooding on the wetland soil properties, further verification required to assess the drain water quality during the rainy season, which is the main contributor for wetland flooding.

\section{References}

1) Scott DA, Jones TA. Classification and inventory of wetlands: A global overview. Vegetatio. 1995;118(1-2):3-16. Available from: https://dx.doi.org/10. 1007/bf00045186. doi:10.1007/bf00045186.

2) Foote AL, Pandey S, Krogman NT. Processes of wetland loss in India. Cambridge University Press (CUP). 1996. Available from: https://dx.doi.org/10. 1017/s0376892900038248. doi:10.1017/s0376892900038248. 
3) Supriyadi, Mustikaningrum I, Herawati A, Purwanto, Sumani. Soil quality assessment in organic and non organic paddy fields in Susukan, Indonesia. Bulgarian Journal of Agricultural Science. 2018;24(5):777-784.

4) Benitez E, Nogales R, Campos M, Ruano F. Biochemical variability of olive-orchard soils under different management systems. Applied Soil Ecology. 2006;32(2):221-231. Available from: https://dx.doi.org/10.1016/j.apsoil.2005.06.002. doi:10.1016/j.apsoil.2005.06.002.

5) Şeker C, Özaytekin HH, Negiş H, Gümüş İ, Dedeoğlu M, Atmaca E, et al. Assessment of soil quality index for wheat and sugar beet cropping systems on an entisol in Central Anatolia. Environmental Monitoring and Assessment. 2017;189(4):135-135. Available from: https://dx.doi.org/10.1007/s10661-0175848-z. doi:10.1007/s10661-017-5848-z.

6) Reddy KR, Kadlec RH, Flaig E, Gale PM. Phosphorus Retention in Streams and Wetlands: A Review. Critical Reviews in Environmental Science and Technology. 1999;29(1):83-146. Available from: https://dx.doi.org/10.1080/10643389991259182. doi:10.1080/10643389991259182.

7) Kowalska JB, Mazurek R, Gąsiorek M, Zaleski T. Pollution indices as useful tools for the comprehensive evaluation of the degree of soil contamination-A review. Environmental Geochemistry and Health. 2018;40(6):2395-2420. Available from: https://dx.doi.org/10.1007/s10653-018-0106z. doi:10.1007/s10653-018-0106-z.

8) Dunnea J, Clarka MW, Corstanjeb R, Reddy KR. Legacy phosphorus in subtropical wetland soils: Influence of dairy, improved and unimproved pasture land use. Ecological Engineering. 2011;37:1481-1491.

9) Snakin VV, Krechetov PP, Kuzovnikova TA, Alyabina IO, Gurov AF, Stepichev AV. The system of assessment of soil degradation. Soil Technology. 1996;8(4):331-343. Available from: https://dx.doi.org/10.1016/0933-3630(95)00028-3. doi:10.1016/0933-3630(95)00028-3.

10) Huang C, Bai J, Shao H, Gao H, Xiao R, Huang L, et al. Changes in Soil Properties before and after Wetland Degradation in the Yellow River Delta, China. CLEAN - Soil, Air, Water. 2012;40(10):1125-1130. Available from: https://dx.doi.org/10.1002/clen.201200030. doi:10.1002/clen.201200030.

11) Lewis DB, Brown JA, Jimenez KL. Effects of flooding and warming on soil organic matter mineralization in Avicennia germinans mangrove forests and Juncus roemerianus salt marshes. Estuarine, Coastal and Shelf Science. 2014;139:11-19. Available from: https://dx.doi.org/10.1016/j.ecss.2013.12.032. doi:10.1016/j.ecss.2013.12.032.

12) Balasubramanian D, Arunachalam K, Arunachalam A. Soil microbial and biochemical properties as affected by floods in different landuse systems of Burachapori Wildlife Sanctuary, northeast India. Tropical Ecology. 2015;56(3):289-302.

13) Ren Y, Li X, Mao D, Wang Z, Jia M, Chen L. Investigating spatial and vertical patterns of wetland soil organic carbon concentrations in China’s Western Songnen Plain by comparing different algorithms. Sustainability. 2020;12:932-932. doi:10.3390/su12030932.

14) Kumar S, Dhankhar R. Trophic state index and assessment of water quality for domestic and agriculture purpose of Bhindawas wetland. Annals of Biology. 2012;28(2):144-151.

15) Allen SA. Chemical analysis of ecological materials. London. Blackwell. 1989.

16) WALKLEY A, BLACK IA. AN EXAMINATION OF THE DEGTJAREFF METHOD FOR DETERMINING SOIL ORGANIC MATTER, AND A PROPOSED MODIFICATION OF THE CHROMIC ACID TITRATION METHOD. Ovid Technologies (Wolters Kluwer Health). 1934. Available from: https://dx.doi.org/10.1097/00010694-193401000-00003. doi:10.1097/00010694-193401000-00003.

17) Andrews SS, Karlen DL, Mitchell JP. A comparison of soil quality indexing methods for vegetable production systems in Northern California. Agriculture, Ecosystems \& Environment. 2002;90(1):25-45. Available from: https://dx.doi.org/10.1016/s0167-8809(01)00174-8. doi:10.1016/s0167-8809(01)00174-8.

18) Edicha J, Chup CP, Yahaya S. Soil organic matter flux in the Federal Capital Territory, Abuja, Nigeria. European Journal of Scientific Research. 2010;44(4):624-631.

19) Czerepko J. A long-term study of successional dynamics in the forest wetlands. Forest Ecology and Management. 2008;255(3-4):630-642. Available from: https://dx.doi.org/10.1016/j.foreco.2007.09.039. doi:10.1016/j.foreco.2007.09.039.

20) Deka RM, Baruah BK, Kalita J. Physico-chemical characteristics of soil of Kapla Beel, A freshwater wetland in Barpeta district, Assam. . Pollution Research. 2008;27(4):695-698.

21) Singh SK, Rai JPN, Singh A. Influence of prevailing disturbances on soil biology and biochemistry of montane habitats at Nanda Devi Biosphere Reserve (NDBR), India during wet and dry seasons. Geoderma. 2011;162(3-4):296-302. Available from: https://dx.doi.org/10.1016/j.geoderma.2011.02.014. doi:10.1016/j.geoderma.2011.02.014.

22) McLaughlin JW, Calhoon EBW, Gale MR, Jurgensen MF, Trettin CC. Biogeochemical cycling and chemical fluxes in a managed northern forested wetland, Michigan, USA. Forest Ecology and Management. 2011;261(3):649-661. Available from: https://dx.doi.org/10.1016/j.foreco.2010.11.019. doi:10.1016/j.foreco.2010.11.019.

23) Givnish TJ, Volin JC, Owen VD, Volin VC, Muss JD, Glaser PH. Vegetation differentiation in the patterned landscape of the central Everglades: importance of local and landscape drivers. Global Ecology and Biogeography. 2008;17(3):384-402. Available from: https://dx.doi.org/10.1111/j.1466-8238.2007.00371. x. doi:10.1111/j.1466-8238.2007.00371.x.

24) RK, SV, TB. Monthly Variation of Heavy Metal and Metal Resistant Bacteria from Uppanar Estuary (South East Coast of India). Research Journal of Microbiology. 2007;2(1):50-57. Available from: https://dx.doi.org/10.3923/jm.2007.50.57. doi:10.3923/jm.2007.50.57.

25) Awashthi SK. Prevention of Food Adulteration Act no 37 of 1954. In: Central and State Rules as Amended for 1999. New Delhi. Ashoka Law House. 2000.

26) Union E. Heavy metals in wastes, European Commission on Environment. 2002. Available from: http://ec.europa.eu/environment/waste/studies/pdf/ heavymetalsreport.pdf.

27) Mahajan G, Das B, Morajkar S, Desai A, Murgaokar D, Kulkarni R, et al. Soil quality assessment of coastal salt-affected acid soils of India. Environmental Science and Pollution Research. 2020. doi:10.1007/s11356-020-09010-w.

28) Dai Z, Li R, Muhammad N, Brookes PC, Wang H, Liu X, et al. Principle Component and Hierarchical Cluster Analysis of Soil Properties following Biochar Incorporation. Soil Science Society of America Journal. 2014;78(1):205-213. Available from: https://dx.doi.org/10.2136/sssaj2013.05.0199. doi:10.2136/sssaj2013.05.0199.

29) Zolfaghari F, Khosravi H, Shahriyari A, Jabbari M, Abolhasani A. Hierarchical cluster analysis to identify the homogeneous desertification management units. PLOS ONE. 2019;14(12):e0226355-e0226355. Available from: https://dx.doi.org/10.1371/journal.pone.0226355. doi:10.1371/journal.pone.0226355. 